\title{
Sinus Maxillaris Mycetoma of Odontogenic Origin: Case Report
}

\author{
Rode MATJAZ ${ }^{1}$ \\ Podboj JERNEJ ${ }^{2}$ \\ Kogoj-Rode MIRELA ${ }^{3}$ \\ ${ }^{1}$ Department of Clinical Oral Pathology, Medical Centre, Ljubljana, Slovenia \\ ${ }^{2}$ Department of Otorhinolaryngology, Faculty of Medicine, Ljubljana, Slovenia \\ ${ }^{3}$ Department of Dentistry, Faculty of Medicine, Ljubljana, Slovenia
}

\begin{abstract}
Fungal infections are on the increase and those of the jaw cavities with Aspergillus species may be connected with the root apices of teeth in the upper jaw. Diagnostic changes in the sinus maxillaris and certain types of facial pain may be indicative of fungal infection. The authors report a case of aspergillosis sinusitis and describe the diagnostic methods and treatment of this infection that may be associated with endodontic treatment.
\end{abstract}

Key Words: aspergillosis, jaw cavities, endodontology, diagnostics.

\section{INTRODUCTION}

Mycotic sinusitises are on the increase worldwide. Among other causes, these conditions are also linked to the extensive use of antibiotics, corticosteroids, and cytostatics. An important factor for the higher number of detected sinus mycoses is better diagnostic techniques, which are mainly enabled by computer tomography and endoscopy (1-3). Anatomic obstacles in the nose corridors are equally important in sinusitises, including fungal sinusitises, because patients may be otherwise without evidence of disease $(1,4)$. Deviations, cristae and spinae of the nose column, pneumatized middle nose conch and other abnormalities in the middle nose corridor disturb normal ventilation and jaw cavity drainage, therefore, thus mitigating an infection.

The most frequent form of rhinosinusal mycoses is the jaw cavity mycetoma $(5,6)$. It is three times more frequent in women than in men and appears during middle age $(7,8)$. It is most often caused by the Aspergillus species fungi, most frequently by Aspergillus fumigatus, while Aspergillus flavus is the most viral.
This species of fungi prospers best in mucus, which is the plausible reason why they also affect the paranasal cavities (2). For growth, it does not need light, but does need glucose, nitrogen, sulfur, phosphor, potassium, calcium, magnesium, iron and zinc (5). Mycotic rhinosinusitises may also be caused by other species of fungi $(8,9)$, however, not as frequently.

As well as the usual way of jaw cavity infection with fungi along the respiratory vias, the authors attribute an increasing importance to odontogenic causes of infection. Although etiology of this type of infection is only rarely proven with certainty, it can often be suspected on the basis of the anamnestic data. Jaw cavity mycosis can arise either from an untreated gangrenous decay of the whole tooth pulp, or after endodontic intervention on the teeth of the maxilla, which are in contact with the sinus, or after insertion of dental implants in this area $(2,10)$.

The clinical picture of a jaw cavity mycetoma does not differ from the repeating chronic inflammation of the cavity sinuses due to other infections. Patients are mainly disturbed by a periodical ulcerous leak from the nose and an unpleasant odor. The illness can

Correspondence: Prof. Matjaz Rode, MDD, PhD, Bratov Ucakar 16, 1000 Ljubljana, Slovenia. e-mail: matjaz.rode@siol.net 
last for years with periodical exacerbations, which respond well to antibiotic treatment. Apart from other complaints, it may cause non-typical facial and tooth pain (5).

A classical X-ray image of paranasal cavities most frequently shows only a larger or smaller shading of the jaw cavity. Dense rounded radiopacities are more seldom seen with calcinations typical of mycetoma, which give an impression of a foreign body in the sinus ("fungal ball") (5). Computer tomography allows precise recognition of the sinus mycosis, clearly showing condensations and calcinations in mycetoma. It is detected by endoscopy of the nose and the affected sinus. The appearance of fungal druses, seen during intervention is typical, but the causative agent can be proven only by mycologic and histologic examinations.

The most successful way of treating jaw cavity mycetoma is by endoscopic surgery in which a large communication and drainage hole are made, in order to

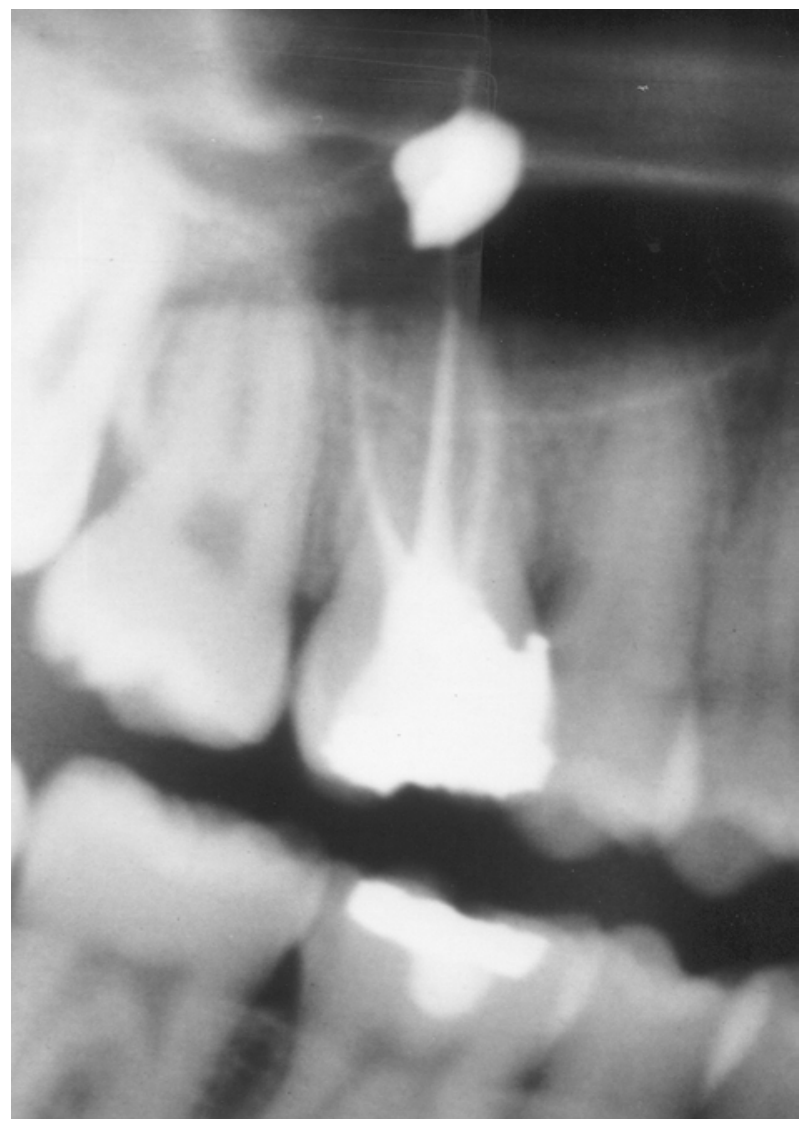

Figure 1. X-ray image of maxillary first molar endodontically treated. Note the appearance of a metal density foreign body at the bottom of the sinus maxillaris. entirely remove the group of fungi. Complete removal of a mycetoma is most frequently possible by access into the sinus through the nose corridor, but sometimes an additional trepanation of the jaw cavity front wall must be made, especially for removal of mycetoma parts and foreign bodies from the alveolar recessus. Additional local or systemic treatment with antimycotics is not necessary after endoscopic surgery (1).

In the period from 1986 through 1999, 36 mycetomas of odontogenic sinus maxillaris were treated at the Clinic of Otorhinology in Ljubljana, and at the Department of Clinical Oral Pathology (Medical Centre Ljubljana) (26 women and 10 men, 30-49 years of age).

\section{CASE REPORT}

A 22-year-old patient had been treated by a dentist for a period of one year before she was hospitalized at the Clinic of Otorhinolaryngology and Cervicofacial Surgery in Ljubljana. Two months after endodontic treatment of the maxillary left first molar, the left cheek began to swell and she also felt periodic pain. She did not notice any ulcerous leak. The X-ray image of the paranasal cavities showed a metal density foreign body at the bottom of the left sinus maxillaris (Figure 1). A sinus trepanation was performed under endoscopic control. The intervention revealed a small, $5 \mathrm{~mm}$ in diameter, fragile mycetomatous formation. Other parts of the sinus mucus and nose column did not show any pathologic changes. The foreign body was removed.

The postoperative course was uneventful. At 4months follow-up, the patient had no subjective difficulties or objective evidence of disease.

The histological diagnosis of the tissue confirmed fungal mycelium, and the mycologic analysis confirmed Aspergillus fumigatus.

\section{DISCUSSION}

Some materials used by dentists to treat tooth pulp disease contain substances that enable fungal growth and mycetoma formation. These materials occur in the pastes used for root filling and contain oxides of zinc, titanium and lead, salts of calcium, barium, sulfur, titanium, zinc and bismuth, and also some organic substances. These stimulate the growth of fungi, especially of Aspergillus. In mycetomas, which are 
actually greater groups of fungal sprouts, apart from calcium salts, some metals that are component parts of endodontic materials have also been found $(5,10)$. When a dentist inserts the material through the apex, and, thus, also into the sinus maxillaris, during the filling of a root canal, ideal conditions for the fungal growth arise. Favorable conditions for growth also originate in non-treated periapical changes and alveolar-sinus fistulas (4).

Thus, we conclude that when searching for causes of jaw cavity fungal inflammation, the professional must consider the possibility that favorable conditions for the fungal growth also originate in non-treated periapical changes in maxillary teeth, and in interventions in which dental materials penetrate into the jaw cavity.

\section{RESUMO}

O número de infecções fúngicas tem aumentado. Infecções fúngicas com a espécie Aspergillus, presentes nas cavidades dos maxilares, podem estar relacionadas com os ápices dos dentes do arco superior. Mudanças diagnósticas nos seios maxilares e certos tipos de dores faciais podem ser indicativos de infecção fúngica. Os autores relatam um caso de sinusite por aspergilose (aspergillosis sinusitis) e descrevem os métodos de diagnóstico e tratamento desta infecção, que pode estar relacionada com o tratamento endodôntico.

\section{REFERENCES}

1. Podboj J. Our experience in treatment of mycotic rhinosinusitis. Med Razgl 1996;35:Suppl 6:265-268.

2. Scully C, Paes de Almeida O. Orofacial manifestations of the systemic mycoses. J Oral Pathol Med 1992;21:289-294.

3. Jonathan D, Lund V, Milory C. Allergic aspergillus sinusitis - an overlooked diagnosis? J Laryngol Otol 1989;103:1181-1184.

4. Buffe P, Nottet JB, Poncet JL. Les sinusites maxillaires aspergillaires. Revue de Laryngologie 1992;113:197-200.

5. Stammberger H, Jakse R. Mykotische Erkrankungen im HNO Bereich. HNO 1987;35:139-176.

6. Molroy CM, Blanshard JD, Lucas S, Michaels L. Aspergillosis of the nose and paranasal sinuses. J Clin Pathol 1989;42:123-127.

7. Jahrsdoerfer RA, Ejercito VS, Johns MM, Cantrell RW, Sydnor JB. Aspergillosis of the nose and paranasal sinuses. Am J Otolaryng 1971;72:6-14.

8. Shugar MA. Mycotic infections of the nose and paranasal sinuses. In: The Principles and Practice of Rhinology. Goldman JL, ed. New York: John Wiley \& Sons; 1987. p 717-734.

9. McGill TJ, Simpson G, Healy GB. Fulminant aspergillosis of the nose and paranasal sinuses: a new clinical entity. Laringoscope 1980;90:748-754.

10. Beck-Mannagetta J. Wie häufig gibt es patognomische Röntgenbilder bei der lokalen, nicht-invasiven KieferhöhlenAspergillos? Dtsch Zahnärztl Z 1997;52:765-767.

Accepted July 22, 2002 